\title{
PENERAPAN MEDIA ANIMASI PADA MATERI BANGUN DATAR SEGIEMPAT DALAM PEMBELAJARAN MATEMATIKA KELAS VII SMP
}

\author{
The Application Of Animation Media On Tetragon In Mathematics Learning Of \\ Grade Vii In Junior High School
}

\author{
Oleh \\ A.Muhajir Nasir, ${ }^{1)}$ Hamzah Upu ' dan Hisyam Ihsan ${ }^{3)}$ \\ muhajirnasir@gmail.com \\ 1) Dosen STIKP Yapim Maros \\ 2) ${ }^{3)}$ Dosen Fakultas Matematika UNM
}

\begin{abstract}
The study aimed at discovering the use of animation media on Mathematics learning at Islamic School (MTs.) Paitana Jeneponto which covered the description on students' activities, students' responses, and the improvement of learning outcomes.

The type of the study was quantitative research, with One Group Pretest-Posttest Design. The population were students of grade VII at MTs. Paitana. The sample of the study were 24 students, selected randomly with assumption that all of the classes of grade VII were homogen in terms of learnin outcomes as the experiment class. Data were collected by using observation sheets of students' activities, students' responses, and the test of learning outcomes. Requirement test for analysis used test of normality. Data were analyzed by employing one sample t-test technique.

The result of the study revealed that (1) the impact of the use of animation media toward students' activities are described as follows: in general, students tend to pay attention on the animation media without other irrelevant activities of the lesson and the students' activities overall was in ideal category; (2) students give positive responses on learning proved more than $80 \%$ or all of the questions received positive responses to more than 50\% students; (3) the mean score of students' pretest was 28.79 with the standard of deviation 10.118 from each of the ideal score 100. The gain score was 0.71 from learning outcomes data which was categorized as high, data were distributed normally with the level of significance 0.269 for normalized gain data. By the t-test, the significance value obtained 0.000 meaning that there was improvement on students' learning outcomes in studying Mathematics after the students taught by employing direct learning model using animation media. The final test indicated as well that 22 out of 24 students (91.67\%) achieved the KKM score on Mathematics learning at MTs. Paitana.
\end{abstract}

Keyword: animation, tetragon, mathematics.

\section{A. PEndahuluan}

Mata pelajaran matematika perlu diberikan kepada siswa agar siswa mampu berpikir logis, analitis, sistematis, kritis, dan kreatif. Berbagai model pembelajaran dapat diterapkan dalam kegiatan belajar mengajar di kelas agar tujuan pembelajaran dapat tercapai, di antaranya Model Pengajaran Langsung (Direct Instruction).

Satoru (2000) menyatakan bahwa penggunaan komputer dalam pembelajaran matematika di Jepang dapat meningkatkan efektivitas pembelajaran, 
karena komputer dapat membantu visualisasi bangun-bangun Geometri, menghitung operasi-operasi bilangan dengan cepat, dan menyelesaikan permasalahan-permasalahan matematika.

Media animasi menjadi salah satu pilihan media pembelajaran yang efektif karena animasi memberikan bentuk visual yang lebih dinamik serta menarik dan memungkinkan sesuatu yang mustahil atau kompleks berlaku di dalam kehidupan sebenarnya direalisasikan di dalam aplikasi tersebut. Media animasi merupakan media pembelajaran yang kompleks dibandingkan media pembelajaran seperti buku, alat peraga, radio dan lain-lain karena animasi telah mencakup unsur audio, visual dan gerakan serta dapat diatur bentuk pergerakannya dengan menggunakan vasilitas sistem kontrol.

Berdasarkan latar belakang di atas maka penulis merasa perlu untuk mengimplementasikan pembelajaran model pengajaran langsung dengan animasi. Oleh karena itulah, penulis termotivasi untuk mengadakan penelitian dengan judul "Penerapan Media Animasi pada Materi Bangun Datar Segiempat dalam Pembelajaran Matematika Kelas VII SMP”.

\section{B. KAJIAN PUSTAKA}

\section{Prestasi Belajar Matematika}

Menurut Winkel (2009) prestasi belajar adalah salah satu bukti yang menunjukkan kemampuan atau keberhasilan seseorang yang melakukan pembelajaran sesuai dengan bobot atau nilai yang berhasil diraihnya. Winkel lebih menekankan prestasi belajar itu pada kemampuan siswa secara umum. Djamarah (2006) mengemukakan bahwa prestasi belajar adalah hasil yang diperoleh berupa kesan - kesan yang mengakibatkan perubahan dalam diri individu sebagai hasil dari aktivitas dalam belajar dan diwujudkan dalam bentuk nilai atau angka.

\section{Media Pembelajaran}

Menurut Sadiman (2010: 6) kata media berasal dari bahasa Latin dan merupakan bentuk jamak dari kata medium yang secara harfiah berarti perantara atau pengantar. Gagne (Sadiman, 2010: 6) menyatakan bahwa media adalah berbagai jenis komponen dalam lingkungan siswa yang dapat merangsang untuk belajar.

Apapun batasan yang diberikan, ada persamaan di antara batasan tersebut yaitu bahwa media adalah segala sesuatu yang dapat digunakan untuk menyalurkan pesan dari pengirim ke penerima sehingga dapat merangsang pikiran, perasaan, perhatian, dan minat serta perhatian siswa 
sedemikian rupa sehingga pembelajaran terjadi.

\section{Animasi}

Animasi menurut Suheri (2006) merupakan kumpulan gambar yang diolah sedemikian rupa sehingga menghasilkan gerakan. Menurut Bustaman (2001: 32), animasi adalah suatu proses dalam menciptakan efek gerakan atau perubahan dalam jangka waktu tertentu, dapat juga berupa perubahan warna dari suatu objek dalan jangka waktu tertentu dan bisa juga dikatakan berupa perubahan bentuk dari suatu objek ke objek lainnya dalam jangka waktu tertentu. Pengertian lain tentang animasi adalah pembuatan gambar atau isi yang berbeda-beda pada setiap frame, kemudian dijalankan rangkain frame tersebut menjadi sebuah motion atau gerakan sehingga terlihat seperti sebuah film Zeembry (2001: 43).

Menurut Macoala (2013), media animasi dalam pembelajaran memiliki beberapa kelebihan yaitu:

a. Media Animasi dalam pembelajaran mampu menyampaikan sesuatu konsep yang kompleks secara visual dan dinamik.

b. Media Animasi digital mampu menarik perhatian pelajar dengan mudah. Animasi mampu menyampaikan suatu pesan dengan lebih baik dibanding penggunaan media yang lain.

c. Animasi digital juga dapat digunakan untuk membantu menyediakan pembelajaran secara maya.

d. Media Animasi dalam pembelajaran mampu menawarkan satu media yang lebih menyenangkan. Animasi mampu menarik perhatian, meningkatkan motivasi serta merangsang pemikiran pelajar yang lebih berkesan.

e. Persembahan secara visual dan dinamik yang disediakan oleh teknologi animasi mampu memudahkan dalam proses penerapan konsep atau pun demonstrasi.

\section{Model Pengajaran Langsung (Direct Instruction)}

Model Pengajaran langsung adalah salah satu pendekatan mengajar yang dirancang khusus untuk menunjang pembelajaran siswa yang berkaitan dengan pengetahuan deklaratif dan pengetahuan prosedural yang terstruktur dengan baik yang dapat diajarkan dengan pola kegiatan yang bertahap, selangkah demi selangkah (Kanreguru, 2009)

'Sintaks model pengajaran langsung disajikan dalam 5 (lima) tahap, seperti ditunjukkan tabel berikut: 
Tabel 1 Sintaks Model Pengajaran Langsung

\begin{tabular}{|c|c|c|}
\hline Fase & Indikator & Peran Guru \\
\hline 1 & $\begin{array}{l}\text { Menyampaikan tujuan } \\
\text { dan mempersiapkan } \\
\text { siswa }\end{array}$ & $\begin{array}{l}\text { Guru menjelaskan tujuan pembelajaran, } \\
\text { informasi latar belakang pelajaran, } \\
\text { pentingnya pelajaran, mempersiapkan } \\
\text { siswa untuk belajar. }\end{array}$ \\
\hline 2 & $\begin{array}{l}\text { Mendemonstrasikan } \\
\text { pengetahuan dan } \\
\text { keterampilan }\end{array}$ & $\begin{array}{l}\text { Guru mendemonstrasikan keterampilan } \\
\text { dengan benar, atau menyajikan informasi } \\
\text { tahap demi tahap }\end{array}$ \\
\hline 3 & Membimbing pelatihan & $\begin{array}{l}\text { Guru merencanakan dan memberi } \\
\text { bimbingan pelatihan awal }\end{array}$ \\
\hline 4 & $\begin{array}{l}\text { Mengecek pemahaman } \\
\text { dan memberikan umpan } \\
\text { balik }\end{array}$ & $\begin{array}{l}\text { Mengecek apakah siswa telah berhasil } \\
\text { melakukan tugas dengan baik, memberi } \\
\text { umpan balik }\end{array}$ \\
\hline 5 & $\begin{array}{l}\text { Memberikan } \\
\text { kesempatan untuk } \\
\text { pelatihan lanjutan dan } \\
\text { penerapan }\end{array}$ & $\begin{array}{l}\text { Guru mempersiapkan kesempatan } \\
\text { melakukan pelatihan lanjutan, dengan } \\
\text { perhatian khusus pada penerapan kepada } \\
\text { situasi lebih kompleks dan kehidupan } \\
\text { sehari-hari. }\end{array}$ \\
\hline
\end{tabular}

\section{METODE PENELITIAN}

\section{Jenis Penelitian}

Jenis penelitian ini adalah One Group Pretest-Posttest Design dengan menggunakan perlakuan pada objek penelitian dengan melibatkan satu kelompok kelas saja sebagai kelas eksperimen tanpa variabel kontrol

\section{Subjek Penelitian}

Penelitian ini dilaksanakan di MTs Paitana tahun ajaran 2012/2013 dengan subjek penelitian adalah seluruh siswa kelas $\mathrm{VII}_{1}$ dengan jumlah siswa 24 orang, terdiri dari 9 laki-laki dan 15 perempuan. Peneliti bertindak sebagai guru matematika di kelas tersebut, dan dalam penelitian ini menggunakan satu observer di kelas tersebut.

\section{Rancangan Penelitian}

Rancangan penelitian ini berbentuk One Group Pretest-Posttest Design sebagaimana disajikan pada Tabel berikut.

Tabel 2 Rancangan Penelitian Eksperimen

\begin{tabular}{rrr}
\hline Tes awal & Perlakuan & Tes akhir \\
\hline $\mathrm{T}_{1}$ & $\mathrm{X}$ & $\mathrm{T}_{2}$ \\
\hline
\end{tabular}

Keterangan :

$\mathrm{T}_{1}$ :Tes awal, tes sebelum perlakuan

$\mathrm{T}_{2}$ :Tes akhir, tes setelah perlakuan

$\mathrm{X}$ :Pembelajaran dengan menggunakan media animasi

\section{Instrumen Penelitian}

Instrumen penelitian ini terdiri dari lembar observasi aktivitas siswa, lembar angket siswa, dan tes prestasi belajar (pretest dan post-test) 


\section{Teknik Pengumpulan Data}

Pengumpulan data dalam penelitian ini diperoleh dari observasi kegiatan siswa, angket dan tes prestasi belajar matematika yang diberikan sebelum dan sesudah siswa diberikan perlakuan.

\section{Teknik Analisis Data}

a. Statistik Deskriptif

Statistik deskriptif digunakan untuk mendeskripsikan karakteristik responden antara lain berupa rata-rata dan standar deviasi responden baik sebelum dan sesudah diberikannya perlakuan. Selain mendekripsikan prestasi belajar siswa, dalam penelitian ini akan dideskripsikan bagaimana perbedaan yang terjadi sesudah siswa diberik perlakuan. Perbedaan tersebut akan ditinjau berdasarkan perhitungan nilai gain ternormalisasi.

b. Statistik Inferensial

Statistika inferensial digunakan untuk menguji hipotesis penelitian. Dalam penelitian ini digunakan analisis statistika One Sample T-test dan uji korelasi Pearson untuk menguji hipotesis penelitian. Namun sebelumnya, terlebih dahulu dilakukan uji prasyarat sebagai berikut.

1) Uji Normalitas

Uji normalitas dimaksudkan untuk mengetahui apakah data yang diteliti berasal dari populasi yang berdistribusi normal atau tidak. Jika nilai sig pada uji Shapiro-Wilk lebih dari alpha (nilai $\mathrm{p}>\alpha=0,05)$, maka data berasal dari populasi yang berdistribusi normal.

2) Uji Homogenitas

Uji homogenitas varian dimaksudkan untuk mengetahui apakah data mempunyai varian yang homogen sebelum digunakannya one sample t-test. $\mathrm{H}_{0}$ diterima apabila nilai sig tabel tes homogenitas varian pada based on mean lebih dari tingkat alpha $(\alpha)=0,05$.

3) Uji Hipotesis

Uji hipotesis dimaksudkan untuk mengetahui apakah hipotesis penelitian yang telah ditentukan diterima atau tidak. Jika nilai sig lebih dari tingkat alpha (nilai $\mathrm{p}>\alpha=0,05$ ), maka hipotesis nol diterima.

\section{HASIL DAN PEMBAHASAN}

1. Deskripsi Aktivitas Siswa 
Tabel 3 Aktivitas Siswa Selama Kegiatan Pembelajaran

\begin{tabular}{|l|l|l|l|l|l|l|}
\hline \multicolumn{1}{|c|}{$\begin{array}{c}\text { Kategori Aktivitas } \\
\text { Siswa }\end{array}$} & I & II & III & IV & $\begin{array}{c}\text { Rata- } \\
\text { rata }\end{array}$ & $\begin{array}{c}\text { Interval } \\
\text { Toleransi } \\
\text { PWI (\%) }\end{array}$ \\
\cline { 2 - 6 } $\begin{array}{l}\text { Memperhatikan media } \\
\text { yang digunakan }\end{array}$ & $18 \%$ & $15 \%$ & $17 \%$ & $22 \%$ & $18 \%$ & $15-25$ \\
\hline $\begin{array}{l}\text { Mendengarkan/ } \\
\text { memperhatikan } \\
\text { penjelasan guru }\end{array}$ & $33 \%$ & $30 \%$ & $35 \%$ & $36 \%$ & $34 \%$ & $30-40$ \\
\hline $\begin{array}{l}\text { Menuliskan materi di } \\
\text { buku catatan }\end{array}$ & $13 \%$ & $13 \%$ & $10 \%$ & $14 \%$ & $12 \%$ & $5-15$ \\
\hline $\begin{array}{l}\text { Memahami/ somul- } \\
\text { menyelesaikan son } \\
\text { soal yang diberikan }\end{array}$ & $16 \%$ & $19 \%$ & $16 \%$ & $13 \%$ & $16 \%$ & $10-20$ \\
\hline $\begin{array}{l}\text { Membandingkan } \\
\text { jawaban atau } \\
\text { berdiskusi dengan } \\
\text { teman sebangkunya }\end{array}$ & $7 \%$ & $9 \%$ & $9 \%$ & $7 \%$ & $8 \%$ & $5-15$ \\
\hline $\begin{array}{l}\text { Mempersentasikan } \\
\text { jawaban, bertanya, } \\
\text { atau menyampaikan } \\
\text { pendapat kepada } \\
\text { teman atau guru }\end{array}$ & $10 \%$ & $8 \%$ & $10 \%$ & $8 \%$ & $9 \%$ & $5-15$ \\
\hline $\begin{array}{l}\text { Aktifitas siswa yang } \\
\text { tidak relevan dengan } \\
\text { kegiatan pembelajaran }\end{array}$ & $3 \%$ & $6 \%$ & $2 \%$ & $0 \%$ & $3 \%$ & $0-5$ \\
\hline
\end{tabular}

Berdasarkan Tabel 3 di atas, diketahui bahwa semua kategori aktivitas siswa yang diamati memenuhi Interval Toleransi PWI (\%) yang ditentukan. Artinya, kriteria pencapaian waktu ideal aktivitas siswa terpenuhi dan syarat lima dari tujuh kriteria batas toleransi waktu ideal yang digunakan terpenuhi. Maka dapat disimpulkan bahwa aktivitas siswa secara keseluruhan pada pembelajaran matematika dengan penerapan media animasi yang dilakukan pada penelitian ini masuk dalam kategori waktu ideal.

\section{Deskripsi Respons Siswa}

Persentase respons siswa terhadap penerapan media animasi pada materi bangun datar segiempat dalam pembelajaran matematika dapat dilhat pada tabel 4 diperoleh informasi bahwa rata-rata $81 \%$ siswa memberikan respons positif terhadap penggunaan media animasi pada materi bangun datar segi empat dalam pembelajaran matematika atau respons positif siswa terhadap pernyataan untuk setiap aspek yang direspons pada komponen pembelajaran diperoleh persentase lebih dari $70 \%$. Dengan demikian, berdasarkan kriteria 
keefektifan respons siswa terhadap bangun datar segiempat dalam penggunaan media animasi pada materi pembelajaran matematika adalah positif.

Tabel 4 Hasil Respons Siswa Terhadap Pembelajaran

\begin{tabular}{|l|l|l|l|}
\hline \multirow{2}{*}{ No } & Pernyataan & \multicolumn{2}{l|}{ Respons Siswa } \\
\cline { 3 - 4 } & $\begin{array}{l}\text { Melalui penggunaan media animasi menjadikan } \\
\text { saya tidak menyukai pelajaran matematika. }\end{array}$ & $8 \%$ & $92 \%$ \\
\hline 2 & $\begin{array}{l}\text { Penyajian materi dengan media animasi membuat } \\
\text { saya tidak tertarik mengikuti pelajaran. }\end{array}$ & $13 \%$ & $88 \%$ \\
\hline 3 & $\begin{array}{l}\text { Pembelajaran dengan media animasi pada materi } \\
\text { bangun datar segiempat mendorong saya untuk } \\
\text { aktif bertanya hal-hal yang masih kurang jelas } \\
\text { kepada guru. }\end{array}$ & $75 \%$ & $25 \%$ \\
\hline 4 & $\begin{array}{l}\text { Penerapan pembelajaran dengan media animasi } \\
\text { menjadikan saya tidak aktif mengikuti pelajaran. }\end{array}$ & $17 \%$ & $83 \%$ \\
\hline 5 & $\begin{array}{l}\text { Tampilan media animasi sangat menarik } \\
\text { Materi yang disajikan dengan media animasi } \\
\text { sukar untuk dipahami }\end{array}$ & $79 \%$ & $21 \%$ \\
\hline 7 & $\begin{array}{l}\text { Materi yang ada pada media animasi sudah cukup } \\
\text { lengkap }\end{array}$ & $75 \%$ & $25 \%$ \\
\hline 8 & $\begin{array}{l}\text { Penyajian materi dengan menggunakan media } \\
\text { animasi dapat membimbing saya untuk lebih } \\
\text { memahami materi bangun datar segiempat. }\end{array}$ & $79 \%$ & $21 \%$ \\
\hline 9 & $\begin{array}{l}\text { Saya merasa tidak senang mengikuti kegiatan } \\
\text { belajar menggunakan media animasi sebagai } \\
\text { media pembelajaran. }\end{array}$ & $17 \%$ & $83 \%$ \\
\hline 10 & $\begin{array}{l}\text { Media animasi membantu saya untuk selalu } \\
\text { mengingat materi yang telah dijelaskan. }\end{array}$ & $79 \%$ & $21 \%$ \\
\hline
\end{tabular}

Keterangan: pernyataan positif : 3, 5, 7, 8 dan 10; negatif : 1, 2, 4, 6, dan 9

\section{Deskripsi Prestasi Belajar Siswa}

Tabel 5 Rekapitulasi Tes Prestasi Belajar Matematika Siswa

\begin{tabular}{lrr}
\hline & Pretest & Posttest \\
\hline Ukuran sampel & 24 & 24 \\
Nilai terendah & 18 & 48 \\
Nilai tertinggi & 50 & 95 \\
Mean & 28,79 & 79,13 \\
Median & 25 & 79 \\
Range & 32 & 47 \\
Standar deviasi & 9,668 & 10,118 \\
Varians & 93,476 & 102,375 \\
Skewness & 0,647 & $-1,154$ \\
Kurtosis & $-0,858$ & 2,753 \\
\hline
\end{tabular}

Pada Tabel 5 terlihat bahwa skor prestasi belajar siswa setelah diajar dengan penggunaan media animasi mengalami perubahan yang positif. Berdasarkan deskripsi prestasi belajar siswa di atas, maka prestasi belajar matematika siswa setelah diajar dengan menggunakan media animasi pada kelas eksperimen dalam penelitian ini dapat dikatakan meningkat. 
Tabel 6 Gain Ternormalisasi Prestasi Belajar Matematika Siswa

\begin{tabular}{lllllll}
\hline & Min & Max & Mean & Varians & Skewness & Kurtosis \\
\hline $\begin{array}{l}\text { Skor Gain } \\
\text { Ternormalisasi }\end{array}$ & 0,32 & 0,94 & 0,71 & 0,019 & $-0,892$ & 1,424 \\
\hline
\end{tabular}

Tabel 6 menunjukkan bahwa ratarata gain ternormalisasi prestasi belajar matematika siswa sebesar 0,71 . Berdasarkan kategori gain ternormalisasi pada tabel 3.3, skor tersebut berada pada kriteria tinggi. Artinya, secara klasikal prestasi belajar matematika siswa pada pokok bahasan bangun datar segiempat setelah diajar dengan menggunakan media animasi mengalami peningkatan yang tinggi. Adapun jika ditinjau dari nilai skewness sebesar -0,892, maka distribusi data gain ternormaslisasi siswa untuk prestasi belajar matematikanya miring ke kanan dan nilai kurtosis 1,424 berarti kurva data termasuk kategori Leptokurtik (meruncing). Nilai-nilai tersebut mengindikasikan bahwa data dominan menyebar pada daerah sedang dan tinggi.

\section{Pencapaian Keefektifan}

\section{Pembelajaran}

Pencapaian efektifan pembelajaran model pengajaran langsung menggunakan media animasi pada materi bangun datar segiempat ditentukan berdasarkan ketercapaian ketuntasan belajar, ketercapaian keefektifan aktivitas siswa, respons siswa terhadap pembelajaran yang positif, serta rata-rata gain ternormalisasi prestasi belajar dapat dilihat pada Tabel 7

Tabel 7 Pencapaian Keefektifan Pembelajaran Model Pengajaran Langsung Menggunakan Media Animasi

\begin{tabular}{llllll}
\hline No. & Aspek Kategori & \multicolumn{2}{l}{ Target Minimal } & Pencapaian & Keterangan \\
\hline 1. & $\begin{array}{l}\text { Ketuntasan belajar } \\
\text { secara klasikal }\end{array}$ & $\begin{array}{l}80 \% \\
\text { mencapai KKM }\end{array}$ & $\begin{array}{l}91,67 \% \text { siswa } \\
\text { mencapai KKM }\end{array}$ & Tuntas \\
\hline 2. & $\begin{array}{l}\text { Respons siswa } \\
\text { terhadap } \\
\text { pembelajaran }\end{array}$ & $\begin{array}{l}70 \% \text { pertanyaan } \\
\text { direspon positif }\end{array}$ & $\begin{array}{l}\text { 100\% pertanyaan } \\
\text { direspon positif }\end{array}$ & Positif \\
\hline & $\begin{array}{l}\text { Aktivitas siswa } \\
\text { dalam } \\
\text { pembelajaran }\end{array}$ & $\begin{array}{l}\text { Aktivitas 1, 2, 4, dan 6 masuk } \\
\text { kategori ideal }\end{array}$ & $\begin{array}{l}\text { Semua aktivitas } \\
\text { masuk dalam } \\
\text { kategori ideal }\end{array}$ & Efektif \\
\hline $\begin{array}{l}\text { Rata-rata gain } \\
\text { ternormalisasi } \\
\text { prestasi belajar }\end{array}$ & $\overline{\mathrm{g}}>0,3$ & $\overline{\mathrm{g}}=0,71$ & Meningkat \\
\hline
\end{tabular}

Berdasarkan kriteria keefektifan pembelajaran model pengajaran langsung pembelajaran, disimpulkan bahwa menggunakan media animasi efektif 
untuk diterapkan pada materi bangun datar segiempat pada siswa kelas VII SMP.
5. Uji Prasyarat Analisis Penelitian

a. Hasil Uji Normalitas

Tabel 8 Hasil Uji Normalitas Data Penelitian

\begin{tabular}{lllll}
\hline Sumber & Nilai- $p$ & $\alpha$ & Keputusan & Kesimpulan \\
\hline $\begin{array}{l}\text { Gain Ternormalisasi } \\
\text { Prestasi Belajar }\end{array}$ & 0.269 & 0,05 & Nilai- $p>\alpha$ & Normal \\
\hline
\end{tabular}

Berdasarkan hasil uji normalitas di atas, diperoleh nilai- $p$ pada uji ShapiroWilk lebih dari 0,05. Karena nilai-p (sig) lebih dari 0,05 maka dapat disimpulkan bahwa data dalam penelitian ini berasal dari populasi yang berdistribusi normal.

b. Hasil Uji Homogenitas

Tabel 9 Hasil Uji Homogenitas Varian Data Penelitian

\begin{tabular}{lccll}
\hline Sumber & Nilai- $p$ & $\alpha$ & Keputusan & Kesimpulan \\
\hline $\begin{array}{l}\text { Gain Ternormalisasi } \\
\text { Prestasi Belajar }\end{array}$ & 0,302 & 0,05 & Nilai- $p>\alpha$ & Varian \\
\hline
\end{tabular}

Dari tabel di atas diperoleh nilai- $p$ lebih dari alpha yang telah ditetapkan. Dengan demikian, dapat disimpulkan bahwa data dalam penelitian ini yang digunakan untuk keperluan uji hipotesis penelitian berasal dari populasi yang

memiliki varian homogen. Dengan
tepenuhinya uji prasyarat normalitas dan homogenitas varian data, maka selanjutnya dalam pengujian hipotesis penelitian dapat dilakukan dengan uji-t.

\section{Hasil Pengujian Hipotesis}

Tabel 10 One Sample T-Test

\begin{tabular}{lcccc}
\hline Sumber & thitung & Nilai- $p$ & Keputusan \\
\hline $\begin{array}{l}\text { Gain Ternormalisasi } \\
\text { Belajar Matematika }\end{array}$ & Prestasi & 24,899 & 0,000 & $\mathrm{H}_{0}$ ditolak
\end{tabular}

$\mathrm{H}_{0} \quad$ :Tidak ada peningkatan prestasi belajar matematika siswa setelah siswa diajar dengan menerapkan model pengajaran langsung dengan menggunakan media animasi

Berdasarkan rangkuman hasil analisis data pada tabel 4.7 diperoleh nilai $\mathrm{t}_{\text {hitung }}=24,889$ dengan nilai- $p=0,000<\alpha$ $=0,05$. Oleh karena nilai- $p<0,05$, maka sesuai dengan kriteria pengambilan keputusan untuk uji hipotesis, dapat disimpulkan bahwa $\mathrm{H}_{0}$ ditolak. Artinya, ada peningkatan prestasi belajar matematika siswa setelah siswa diajar dengan menerapkan model pengajaran 
langsung dengan menggunakan media animasi.

\section{Pembahasan}

a. Aktivitas Siswa dalam Pembelajaran

Hasil pengamatan observer terhadap aktivitas siswa pada pembelajaran model pengajaran langsung menggunakan media animasi, menunjukkan bahwa dari tujuh aspek yang diamati, ketujuh aspek tersebut memenuhi kriteria efektif.

Secara umum, aktivitas siswa berada pada kriteria batasan efektif, walaupun pada pertemuan awal masih ada siswa yang melakukan aktivitas yang tidak relevan dengan kegiatan pembelajaran seperti bercerita atau mengganggu teman sebangkunya, namun pada pertemuan-pertemuan berikutnya kegiatan siswa yang tidak relevan tersebut terus berkurang, sehingga dapat disimpulkan bahwa aktivitas siswa tergolong efektif (aktif).

b. Respons Siswa terhadap Pembelajaran

Dari hasil angket respons siswa, pada umumnya siswa memberikan respons positif terhadap pembelajaran model pengajaran langsung menggunakan media animasi. Hal ini ditunjukkan dari 85\% siswa memberikan respons positif terhadap pelaksanaan pembelajaran menggunakan media animasi, $78 \%$ siswa menyatakan animasi yang digunakan menarik dan materinya lengkap, dan $80 \%$ siswa merasa senang, lebih memahami materi, dan terbantu dengan media animasi. Data tersebut menunjukkan bahwa $100 \%$ atau seluruh pertanyaan direspons positif oleh lebih dari $80 \%$ siswa, hal ini mengindikasikan bahwa pembelajaran yang dilakukan telah efektif. Hal ini sejalan dengan kriteria pembelajaran efektif yaitu jika respons siswa terhadap pembelajaran sekurangkurangnya $70 \%$ dari semua pertanyaan direspons secara positif oleh minimal 50\% siswa (Nurdin, 2007).

c. Prestasi Belajar Siswa

Penerapan model pengajaran langsung menggunakan media animasi memberikan pengaruh positif terhadap prestasi belajar matematika siswa. Pengaruh tersebut dapat dijelaskan oleh nilai rata-rata tes hasil belajar matematika yang diukur melalui tes awal sebelum siswa diberi perlakuan dan tes akhir setelah siswa diberi perlakuan, dimana nilai rata-rata siswa pada tes awal adalah 28,79 kemudian nilai rata-ratanya meningkat menjadi 79,13 pada saat tes akhir pembelajaran. Tes akhir juga memperlihatkan bahwa 22 dari 24 siswa $(91,67 \%)$ telah mencapai nilai KKM matapelajaran matematika di MTs Paitana - Jeneponto yaitu 70.

Berdasarkan uraian di atas, dapat disimpulkan bahwa pembelajaran dengan 
menerapkan model pengajaran langsung dengan menggunakan media animasi pada kelas VII MTs. Paitana dapat meningkatkan prestasi belajar matematika siswa.

\section{E. KESIMPULAN DAN SARAN}

1. Kesimpulan

a. Aktivitas siswa dalam pembelajaran matematika dengan media animasi menggunakan model pengajaran langsung masuk dalam kategori ideal.

b. Rata-rata $81 \%$ siswa memberikan respons positif terhadap media animasi pada materi bangun datar segiempat dan $100 \%$ atau seluruh pertanyaan direspons positif oleh lebih dari 50\% siswa. Dengan demikian, berdasarkan kriteria keefektifan respons siswa terhadap media animasi pada materi bangun datar segiempat adalah positif.

c. Rata-rata gain ternormalisasi prestasi belajar matematika siswa sebesar 0,71 , skor tersebut berada pada kriteria tinggi. Nilai probabilitas dari hasil analisis one sample t-test adalah $0,000<\alpha=0,050$, berarti $\mathrm{H}_{0}$ ditolak. Dari kedua hal tersebut dapat dikatakan bahwa prestasi belajar matematika siswa pada pokok bahasan bangun datar segiempat setelah diajar dengan menggunakan media animasi mengalami peningkatan yang tinggi. d. Pembelajaran model pengajaran langsung menggunakan media animasi efektif untuk diterapkan pada materi bangun datar segiempat pada siswa kelas VII SMP.

\section{Saran}

a. Pada pembelajaran matematika pokok bahasan segiempat, guru disarankan untuk menerapakan model pengajaran langsung dengan media animasi untuk meningkatkan prestasi belajar siswa.

b. Diharapkan penelitian seperti ini juga dilakukan pada materi pelajaran matematika pokok bahasan yang lain, membuat siswa tertarik, senang, dan aktif belajar matematika untuk mengetahui model, metode dan media yang cocok dalam rangka meningkatkan prestasi belajar matematika siswa pada pokok bahasan tertentu baik pada tingkat SMP maupun pada tingkat SMA.

c. Untuk penelitian selanjutnya, bagi peneliti yang berminat mengembangkan penelitian ini, diharapkan mencermati keterbatasan penelitian ini yang telah dikembangkan, sehingga penelitian selanjutnya dapat menyempurnakan hasil penelitian ini. 
DAFTAR PUSTAKA

Bustaman, Burmansyah. 2001. Web Design dengan Macromedia Flash MX 2004. Andi Offset, Yogyakarta.

Djamarah, Syaiful Bahri. 2006. Strategi Belajar Mengajar. Rineka Cipta, Jakarta

Kanreguru. 2009. Model Pengajaran Langsung (Direct Instruction). http://kanreguru.wordpress.com/200 9/09/12/57. Diakses pada tanggal 24 November 2012.

Macoala, Tri. 2013. Media Animasi dalam Pembelajaran.

http://blogmediapembelajaranguru.b logspot.com/search/label/Media\%20 Animasi\%20Dalam\%20Pembelajara n. Diakses pada tanggal 5 September 2013.

Nurdin. 2007. Model Pembelajaran Matematika yang Menumbuhkan Kemampuan Metakognitif Untuk Menguasai Bahan Ajar. Disertasi tidak diterbitkan.

Sadiman, Arief S. 2010. Media Pendidikan (Pengertian, Pengembangan, dan Pemanfaatannya). Rajawali Pers, Surabaya.

Satoru, Y. 2000. Using Computer in School Education. In O. Toshio (Ed.), Mathematics Education in Japan. Japan Society of Mathematics Education, Tokyo.

Suheri, Agus. 2006. “Animasi Multimedia Pembelajaran", Jurnal Media Teknologi, Vol. 2, No. 1. Universitas Suryakencana, Cianjur
Winkel, W.S. 2009. Psikologi Pengajaran. Media Abadi, Yogyakarta.

Zembry. 2001. Animasi Web dengan Macromedia Flash 8. Elex Media Komputindo, Jakarta. 